\title{
The evolution of the hospital from antiquity to the end of the middle ages
}

\author{
L Cilliers, Professor, Department of English \& Classical Culture, University of the Free \\ State \\ FP Retief, MB ChB (UCT), D Phil (Oxford), MD(Stell), MRCP; FRCP (Edinburgh)
}

\section{Abstract}

The evolution of the hospital is traced from its onset in ancient Mesopotamia towards the end of the $2^{\text {nd }}$ millennium to the end of the Middle Ages. Reference is made to institutionalised health care facilities in India as early as the $5^{\text {th }}$ century $\mathrm{BC}$, and with the spread of Buddhism to the east, to nursing facilities, the nature and function of which are not known to us, in Sri Lanka, China and South East Asia. Special attention is paid to the situation in the Graeco-Roman era: one would expect to find the origin of the hospital in the modern sense of the word in Greece, the birthplace of rational medicine in the $4^{\text {th }}$ century $\mathrm{BC}$, but the Hippocratic doctors paid house-calls, and the temples of Asclepius were visited for incubation sleep and magico-religious treatment. In Roman times the military and slave hospitals which existed since the $1^{\text {st }}$ century AD, were built for a specialized group and not for the public, and were therefore also not precursors of the modern hospital. It is to the Christians that one must turn for the origin of the modern hospital. Hospices, initially built to shelter pilgrims and messengers between various bishops, were under Christian control developed into hospitals in the modern sense of the word. In Rome itself, the first hospital was built in the $4^{\text {th }}$ century AD by a wealthy penitent widow, Fabiola. In the early Middle Ages $\left(6^{\text {th }}\right.$ to $10^{\text {th }}$ century), under the influence of the Benedictine Order, an infirmary became an established part of every monastery. During the late Middle Ages (beyond the $10^{\text {th }}$ century) monastic infirmaries continued to expand, but public hospitals were also opened, financed by city authorities, the church and private sources. Specialized institutions, like leper houses, also originated at this time. During the Golden Age of Islam the Muslim world was clearly more advanced than its Christian counterpart with magnificent hospitals in various countries.

\section{Abstrak}

Die ontwikkeling van die hospitaal word nagegaan vanaf die vroegste tye in antieke Mesopotamië aan die einde van die 2 de millennium v.C. tot die einde van die Middeleeue. Daar word verwys na geïnstitusionaliseerde gesondheidsorg fasiliteite in Indië in die 5 de eeu v.C., en met die verspreiding van Boeddhisme na die Ooste, na verplegings-fasiliteite van onbekende aard en funksie ook in Sri Lanka, Sjina en Suid-Oos Asië. Besondere aandag word geskenk aan die situasie in die Grieks-Romiense era: ' $n$ mens sou dink dat die oorsprong van die hospitaal in die moderne sin van die woord in Griekeland, die geboorteplek van rasionele geneeskunde in die 4 de eeu v.C. ontstaan het, maar die Hippokratiese dokters het siekes tuis besoek, en die tempels van Asklepios is besoek vir die inkubasie-slaap en magies-religieuse behandeling. In die Romeinse tyd is militêre- en slawe-hospitale gebou vir ' $n$ gespesialiseerde groep mense en nie vir die publiek nie, en kan dus ook nie beskou word as voorlopers van die moderne hospitaal nie. Dit is na die Christene wat ons ons moet wend vir die oorsprong van die moderne hospital. Tehuise wat aanvanklik gebou is om pelgrims en boodskappers tussen verskillende biskoppe te huisves, is onder die beheer van die Christene ontwikkel in hospitale in die moderne sin van die word. In Rome self het die eerste hospitaal in die 4de eeu n.C. tot stand gekom deur die bemiddeling van ' $n$ ryk weduwee, Fabiola. Onder invloed van die Benediktynse Kloosterorde in die vroeë Middeleeue (6de tot 10 de eeu) het ' $n$ siekehuis " $n$ gevestigde deel van elke klooster geword. Tydens die laat Middeleeue (na die 10de eeu) het monastiese siekehuise verder uitgebrei, en hospitale vir die publiek het ook nou tot stand gekom, gefinansier deur die stadsvaders, die kerk en privaat bronne. Gespesialiseerde instellings soos melaatse hospitale het ook nou ontstaan. Tydens die Goue Eeu van Islam is manjifieke hospitale in Moslemlande gebou wat in die 13 de en 14de eeue duidelik meer gevorderd as hul Christelike eweknieë was.

\section{Introduction}

Public health was until quite recently very low down on the list of priorities in the Western world - in fact, it only became a national objective in some countries in the late $18^{\text {th }}$ century. This is, however, not surprising when one considers all the forces working against it since the beginning of Western civilization, especially in Greece and Rome. Various factors pre- vented the early development of an adequate health service, for instance ignorance, an unsympathetic attitude towards the sick, superstition and religious beliefs and practices. There were, however, also positive measures taken quite early, by the Roman government in particular, to promote public health, such as the appointment of state physicians, free medical services to the poor, and the provision of a relatively advanced infrastructure for health care in the form of several aqueducts to 
provide sufficient fresh water for the population, a network of gigantic sewers underneath the city for the disposal of sewage, and numerous public baths all over the city.

From a modern point of view, however, the most important and lasting contribution of the ancients to public health is the establishment of the hospital in the modern sense of the word, i.e. an institution where the sick and disabled could receive treatment for a period of time. It is, strangely, not in Greece, the birthplace of rational medicine in the $4^{\text {th }}$ century $\mathrm{BC}$, that our concept of a hospital has a parallel, nor in the temples of Asclepius, the Greek god of healing, or in the Roman military and slave hospitals that existed since the $1^{\text {st }}$ century AD. It is to the Christians that one has to turn to find the origin of the modern hospital - paradoxically, because in other respects Christianity had a very negative effect on medicine (anatomy was denounced, human dissection was prohibited because a man's body is the temple of the Holy Ghost, the occurrence of miracles advanced superstition, and diseases were regarded as a punishment for sin). The Christians' contribution lay another plain, namely compassion with and caring for the sick. Under their control hospices built to shelter pilgrims and messengers between bishops developed into hospitals in the modern sense of the word.

In this article the evolution of the hospital will be traced from its onset to the end of the Middle Ages. Special attention will be paid to the situation in the Graeco-Roman era and the role of the early Christians in this evolutionary process, since the influence this had on developments in later ages is a contribution not fully recognized in discussions of the history of the development of the hospital.

\section{Definition of terms}

A hospital is defined as a room, rooms or building specifically employed for the investigation and continued treatment of illness.

The words 'hospital', 'hôtel', 'spital' and 'hospice' are all derived from the Latin word hospitium meaning 'a place of entertainment for strangers, a lodging, an inn, a guest-chamber' (Lewis \& Short 1958: 867). In late Christian times such hospitia were often attached to monasteries and primarily intended for accommodating pilgrims. Today a hospice usually indicates a home for the terminally ill. The word 'hôtel' is an early French term, and is a forerunner of the present word which refers to a building offering accommodation to paying guests - with no connection to illness (Aitken 1984:9-11).

The word 'infirmary' (from Latin infirmarium) originally referred to a room or rooms attached to a monastery for the treatment of diseased monks (Aitken 1984: 9-11). In the Roman world a valetudinarium referred to a hospital initially solely for the treatment of military personnel, but the word was later also used to denote hospitals for the civic population (Scheider 1953: 262-264). In the monastic period the term 'nosocomium' came into use to indicate a small Roman type hospital, while the Greek word 'xenodocheion' which initially denoted a home for strangers and the poor, eventually referred to charitable hospitals in the early Christian era (Allen 1990: 447-450).
During the 'Golden Age of Islam' ( $9^{\text {th }}-13^{\text {th }}$ centuries) the Persian word bimaristan denoted a hospital, while maristan referred to an institution for the insane (Major 1954: 229; Porter 1997: 105).

\section{Earliest times}

There is some evidence that the earliest 'hospitals' known to us may have been in ancient Mesopotamia. Reiner (1964: 544549) presents evidence that royal physicians at Assyrian and Babylonian courts towards the end of the $2^{\text {nd }}$ millennium BC cared for ill court singers in what were probably elementary hospitals or nursing homes. Classical sources also refer to possible hospitals in the Hellenistic Age attached to the Egyptian temples for Saturn in places like Heliopolis, Memphis and Thebes. However, these were of later origin and probably referred to sleeping accommodation in temple precincts, rather like that associated with the subsequent Asclepian cult (Aitken 1984: 7).

The Buddhist religion with its roots in $6^{\text {th }}$ century BC India. led to the creation of a monastic system, which, as with subsequent Christianity, gave rise to institutionalised health care facilities in and around these monasteries as early as the $5^{\text {th }}$ century $\mathrm{BC}$. The nursing profession may also have originated here $\left(5^{\text {th }}\right.$ century BC), and we are told that Sri Lankan hospitals date back to $431 \mathrm{BC}$. We know very little about the nature and function of these institutions, but the great Indian king, Asoka, is credited with the construction of numerous hospitals for humans and also for animals during the $3^{\text {rd }}$ century BC (Aitken 1984: 7; Haeger 1988: 53-54). With the eastward spread of Buddhism, hospitals, almshouses and convalescent homes also appeared in China (perhaps as early as the $5^{\text {th }}$ century BC) and South East Asia. The precise nature of these hospitals is obscure (Major 1984: 100; Philips 1993:149; Chrystal 2000: 536).

In antiquity the Mosaic laws covered health matters extensively, but the Jewish nation is not associated with the founding of hospital systems (Major 1954: 55-65). The Bible does not mention such institutions, but we do know of persons treated for illness in private homes, e.g. the child in Zarephath (I Kings 17. 17-24), Lazarus (John 11. 6-25), the centurion's child (Luke 7. 1-9), the illness of king Ahaziah (2 Kings 1.1-16), and the Good Samaritan in the parable (Luke 10. 34-35).

\section{Graeco-Roman era}

Primitive health care associated with the temples of Asclepius are considered by many to have been the forerunners of hospitals as we know them today (Thompson 1975: 3,4). Founded at Epidaurus in the $5^{\text {th }}$ century $\mathrm{BC}$, the Asclepian cult revolved around temple complexes usually built at scenic, wooded sites with an abundant water supply. Asclepieia were later built all over the Roman Empire, and flourished up to 391 AD when as pagan temples, they were officially closed by the Christian emperor Theodosius I. Their structure was fairly standardized, usually consisting of large rooms, closed on three sides, orientated to the sun and opening to the south with a row of pillars in the form of a Greek stoa (portico). Big Asclepieia, like that at Pergamum, included treatment halls, libraries, a stadium, baths and latrines. These temples of Asclepius did, however, not have facilities for the long-term treatment of sick patients, and 
should rather be seen as the equivalent of modern-day hydropathic establishments such as Lourdes.

Patients normally entered the temple for incubation sleep in the stoa. Their dreams were then interpreted by priests, who also suggested therapy (Thompson 1975: 3,4). The hypochondriacal Aelius Aristides, a Roman orator of the $2^{\text {nd }}$ century AD, for instance relates how he spent some time as a patient in the home of an Asclepian temple warden, and how in consultation with a physician he was given a therapeutic medicament after his dreams had been interpreted (Aristides, Orations 48. 34, 35, 46-49). Therapy was mainly of magico-mystic nature, and completely alien to the co-existing Hippocratic medicine which was based on contemporary scientific knowledge and abhorred the occult in medicine (there was, however, ironically, a famous Asclepieion on the island of Cos, Hippocrates' birthplace).

The Hippocratic doctors visited and treated patients at their homes and performed the occasional surgical procedure, but there is no evidence in Classical Greece of the use of hospitals in the modern sense of the word. There are references to the iatreia and taberna medica, more or less the equivalent of the Greek and Roman doctor's consulting room, but although it is accepted that under special circumstances these rooms might have been put to short-term use as hospital equivalents (Woodhead 1952: 245), they cannot be compared with the modern concept of a hospital (Harig 1971: 184-185). There is, however, suggestive evidence that rooms in private homes were occasionally adapted for longer term medical treatment (Major 1954: 121-136; Woodhead 1952; 245; Harig 1971: 183).

The first official step taken by the Roman government in public health care - other than the passing of various laws in this regard (Cilliers 1993) - was the establishment in $293 \mathrm{BC}$ of a temple of Aesculapius on the Tiber island in the aftermath of a disastrous plague. In the crisis the Senate took the traditional step and consulted the prophetic Sibylline books; the recommendation was to import the cult of Asclepius, the Greek god of medicine from its chief centre at Epidaurus. Tradition has it (Ovid, Met. 15. 669ff., Livy 10. 47 and Valerius Maximus 1.8.2) that a serpent (the symbol of the god) came on board the ship at Epidaurus of its own accord, and when the mission arrived at Rome, it swam ashore to an islet in the Tiber. After the plague had subsided, the Romans in gratitude for their deliverance built a temple on the island to the god (whom they called 'Aesculapius' in Latin). In prosaic terms this myth explains that the Roman state, due to the unsophisticated stage in which health care was in the $3^{\text {rd }}$ century BC, sought outside assistance in this crisis. The advice from the priests in Epidaurus was that it would be more hygienic to treat the sick outside the built-up area of the city, therefore the temple of Aesculapius was built on an island in the Tiber, outside the precincts of Rome. This Asclepieion later became known as the 'Slave hospital' because of the accumulation of slaves taken there when chronically ill (to avoid expenses for the owners) and never re-collected by their masters (according to Suetonius, Claud. c. 25 and Digesta 40.8 .2 such slaves were on recovery freed by an edict of the emperor Claudius). In Christian times this hospital became famous as the St. Batholomew Hospital and provided shelter for sick pilgrims - a function which it has in effect retained, since on the site once occupied by the ancient temple there now stands a modern hospital, run by a religious order (Staccioli 1989: 60).

With the probable exception of valetudinaria (described below), ancient Rome, as was the case in Greece, had no public institution where sick civilians could be treated for a longer period of time (Majno 1975: 393). The poorer patients were brought to the doctor's iatreion/taberna where they were treated and then sent home, while the rich were visited at home by the doctor. This custom of treating the sick at home (Celsus, Med. 1.65; Cato, Agr. I.1 and 2; Columella, Rust. XI.1.18; XII.1.60) still obtained in the time of the Roman Empire, as is evident from a description by Tacitus (Ann. IV.63) of a disaster which took place in a small town near Rome when an amphitheatre collapsed, after which the injured were taken to private houses where they were treated by physicians. If a hospital had existed, it would have been there, not to private houses, that the injured would have been taken. Even as late as the $3^{\text {rd }}$ century $\mathrm{AD}$ there is still no evidence of hospitals, as is clear from a remark made by Aelius Lampridius (SHA, Alex. Sev. c.47) that the emperor Alexander Severus (AD 222-235) distributed those who were seriously ill between the individual families to be cared for.

With the extension of the Roman Empire, however, when it was no longer possible to send wounded and sick soldiers home for treatment, military hospitals began to be established. Two kinds of hospitalisation were traced: permanent fort hospitals erected at strategic points (valetudinaria), and temporary field hospitals at the front during active campaigns (Scheider 1953: 262-264; Thompson 1975: 4-6; Jackson 1988: 133-137).

The first valetudinarium was probably built in the $1^{\text {st }}$ century $\mathrm{AD}$ at Carnuntum (near Vienna). These soldiers' hospitals became part of established Roman fort architecture and were usually placed near the outer wall, in a quiet part of the fortification. Valetudinaria were placed in major as well as in smaller forts for auxiliary troops - the size varying with the size of the fort. The larger hospitals traditionally consisted of four wings, with a central open courtyard. The number of wards roughly matched the number of centuries in the legion and accommodated no more than three beds each, and were designed for maximal privacy. Usually there were treatment rooms, a dispensary, staff quarters, and washing, cooking and latrine facilities. Calculations suggest that about $5 \%$ of the unit's strength could be accommodated, although this number could easily be doubled by utilizing corridors and ancillary rooms.

Each military unit had its medical assistants (milites medici or capsarii - named after the bandage box, capsa) for casualties in the heat of battle. Behind the lines the field hospital (housed in tents) was the responsibility of the camp prefect, second-incommand and most experienced soldier of the unit. It was actually run by the optio valetudinarii, a junior $\mathrm{HQ}$ officer who was an administrator rather than a doctor. Adequate supply lines to these field hospitals had high priority; in times of starvation the army was the last to suffer. The number and experience of medical staff varied according to the size and prestige of the unit, and staff were probably organized into a hierarchy of military doctors also serving the valetudinaria. There was also a specialised person (the marsus) who looked after snake-bites and other problems of envenomisation (the Marsi were a mountain tribe famous for miraculous snake-bite 
Although we have no archaeological proof of civilian hospitals (Jackson 1988: 65), there is evidence that hospitals, also called valetudinaria, were later also established for the civilian population and upper classes in particular, for imperial staff in provincial cities (probably private institutions), and for gladiators and slaves on large farms (latifundia) (Harig 1971: 189, 193-195; Thompson \& Golden 1975: 4). Landowners realized the necessity of keeping their labour force healthy in order to ensure that they could fulfil their function. (In a treatise on agriculture Columella (Rust. XI.1.18), a contemporary of St. Paul, specifically pointed out the need for providing such valetudinaria for slaves.) There is little information on how these institutions were run, but they were probably a combination of private and state-run establishments. Although Woodhead (1952: 245) suggests that doctors' tabernae often evolved into sanatoria and small house-hospitals (nosocomia), this is little more than speculation. Harig (1971: 183-187) warns that evidence for pronouncing even the well-known 'physician's home' in Pompeii a house-hospital, is slim. However, he speculates that serious accident cases might well have received prolonged therapy in a doctor's house. We therefore arrive at the strange conclusion that the valetudinaria played no direct role in the evolution of the public hospital - they were established for a particular purpose and for a particular class. Not even the term 'valetudinarium' survived, for when hospitals for the general public did arise, they initially became known by the Greek term xenodochia (Allan 1990: 446-447). Well to do households did however have their own treatment quarters for the ill (Seneca, De Ira 1.16.4).

\section{The christian era}

Even during the early phase of the Christian era when Christianity suffered severe religious persecution, their selfless dedication to relief of the suffering of the poor and ill, was remarked on by historians (Cyprian, De mortalitate VI.1-2; Eusebius, Hist. Eccl. IX. 7.15-8.3). The Christians' typical attitude towards the sick was based on Christ's parable of the Good Samaritan - mercy and compassion for anyone in need. This ethos of caring did however not translate into action regarding hospitalisation until the emperor Constantine promulgated his Edicts of Toleration in 311 and 313 granting religious freedom. And then the Christians ' acts of mercy blurred the distinction between assistance to the poor, the aged, the insane and the ill - so that charitable actions, concentrating on the needs of the wretched, often did not differentiate between assistance for paupers, pilgrims, orphans and the diseased (Thompson \& Golden 1975: 6; Ferngren \& Amundsen 1996: 2971-2975). The earliest hospices, called xenodocheia in the mainly Greekspeaking East, initially built to shelter pilgrims and messengers between the various bishops, for instance eventually housed disadvantaged people as well as diseased and mentally infirm persons. In the course of time, many of these developed into standard hospitals (Allen 1990: 447). By the $4^{\text {th }}$ century xenodocheia were well-known institutions in the West as well, mainly because the emperor Julian the Apostate (361-363) in his attempt to revive paganism tried to attract converts by establishing xenodocheia such as the Christians had. In a letter to Arsacius, his pagan high priest in Galatia, Julian wrote: 'In every city establish xenodocheia in order that strangers may profit by our benevolence' (Julian, Ep. 49). About a cen- tury later (470) we also find the law of the emperors Leo and Anthemius ordering the establishment of xenodocheia ( $\mathrm{Co}$ dex Justiniani I.i. tit.3).

With the rapid rise of Christian monasticism, it was logical that charitable endeavours would often emanate from monasteries. Infirmaries originated as health care facilities inside monasteries, designed for the care of the monks. In time infirmaries also took in civilian patients, and even later treatment originally supplied by the monks themselves, was supplemented by help from physicians from outside the institution. In this way monasteries played a vital role in promoting health care and developing hospitals. These hospitals were now supported by Christian charity, and were no longer founded on economic considerations as had largely been the case in earlier Roman times (Thompson \& Golden 1975: 6).

St. Basil of Caesarea (Cappadocia) was a pioneer in establishing suitable hospitalisation and care of the disabled and sick. In 369 he founded the celebrated Basilica at Caesarea, comprising a hospital which apparently had as many wards as there were diseases, and even included a section for lepers who had previously been kept in isolation and were now for the first time cared for. The hospital also had extended quarters for medical staff, workshops, hospices for travellers and the poor, as well as an industrial school. We happen to have a detailed description of this hospital in an oration of Gregory of Nazianus, who delivered St. Basil's funeral oration (Orations xliii). At St. Basil's insistence, hospitals were also built in neighbouring regions, and the Eastern Roman Empire often gave state assistance. At Edessa, for instance, a 300 bedded hospital was established by St. Ephraim in the aftermath of a plague in 375 . In the following century a series of monastery-based hospitals, often with associated buildings for orphans and the poor, sprang up in many cities. In Rome the first hospital was founded in 390 by a Roman lady, Fabiola, a wealthy widow who sought absolution by spending her wealth on charitable works (recorded by Jerome, Ep. Ixxvii, Ad Oceanum de morte Fabiolae). Two other wealthy ladies, Pulcheria and Pauline, later followed her example and built or endowed hospitals in respectively Constantinople and Jerusalem. The Empress Eudoxia (401465 ) also ordered the building of a hospital in Jerusalem (Aitken 1984: 9-11; Allan 1990:452-454).

The fall of Rome in 476 precipitated a prolonged period of developmental stagnation in Europe (the so-called Dark Ages), but chiefly because of Christian monastic influences hospitalisation still moved forward.

\section{Medieval times}

\section{Early Middle Ages $\left(6^{\text {th }}\right.$ to $10^{\text {th }}$ centuries)}

By the middle of the $6^{\text {th }}$ century the principle of the establishment of hospitals was securely established in the Eastern as well as the Western part of the Roman Empire, due also to the support of various monarchs. Childebert, King of the Franks, founded the Hôtel Dieu in Lyons in 542, and Theodoric the Great (493-526) encouraged any Christian initiative concerned with hospitalisation. Charlemagne (747-814) promulgated a decree that a school, monastery and hospital be attached to 
every cathedral built in his territory (Aitken 1984: 10,11; Haeger 1988: 55, 70, 71). The term 'xenodocheion' now began to give place to 'hospitalium' - in a letter written in AD 796, the English scholar and ecclesiastic, Alcuin, urges Eanbald II, Archbishop of York, to found in his diocese 'xenodochia, id est hospitalia' (Wallach 1951: Letter 56, Ad Eanbaldum).

With the founding of a monastery and hospital at Monte Casino in Italy in 529, St. Benedict of Nursia launched one of the most influential of all Medieval initiatives in the field of hospitalisation. He insisted on excellence and dedication in the care of illness, and in time his Benedictine Order became the model for later monastic establishments (Benedict's original Rule called for the establishment of an infirmary in every monastery and placed the care of the sick 'above and before every other duty' (Green 1985: 200 and 240). In 742 a Church Council decreed that all monks and nuns should run their lives, monasteries and hospitals according to the Benedictine Rule. Monte Casino was sacked by the Lombards in the $6^{\text {th }}$ century, rebuilt in the next century and again sacked (by the Saracens) in 884 . In the $10^{\text {th }}$ century it was finally reconstructed (Aitken 1984: 11; Major 1954: 272) (but tragically razed to the ground during the $2^{\text {nd }}$ World War).

Other famous monastic hospitals built at this time included that at Merida, Spain (580), St. John's Hospital at Ephesus (610), Pantokrator in Constantinople ( $7^{\text {th }}$ century), Hôtel Dieu at Paris (651), Montpellier (738), St. Albans in Engeland (794), St. Maria della Scala, Siena (898), and St. Bernard's Hospital in the Swiss Alps (962) (Aitken 1984: 12).

\section{Late Middle Ages (beyond the $10^{\text {th }}$ century)}

Gradually the driving force behind the hospitalisation in Europe changed from being almost exclusively monastery-associated to greater participation by civil authorities. The monastic infirmaries continued to expand, but in large centres the City Fathers initiated hospitals driven by civil support, whilst church authorities also opened public hospitals. And in addition specialised institutions like leper hospitals made their appearance (Aitken 1984: 12,13; Porter 1997: 122).

5.2.1 Monastic institutions gradually expanded their medical services, previously restricted to infirmaries, to the community. Famous new hospitals appeared, like St. Bartholomew's (1137), St. Mary's (1179) and St. Thomas (1215) in London, the Holy Cross hospital in Winchester (1132) and St. John's in Canterbury (1118). During the $12^{\text {th }}$ century a monastic order was founded by Pope Innocent III, which led to the establishment of Hospitals of the Holy Ghost in most major cities. It was said that Islamic hospital design greatly influenced the construction of the first of these hospitals, the Santa Spiritus in Rome (1198).

5.2.2 The public hospital movement in large cities was financed by city authorities as well as the Church and even private sources. Lay physicians played an increasingly important role, especially after the Church placed a ban on monks practising outside monasteries.
In Islamic Jerusalem the Order of the Hospital of St. John was founded by Brother Gerhard in the $13^{\text {th }}$ century as a charitable organisation caring for sick pilgrims in the Holy Land. A warrior element developing from the order took part in the Crusades, and when Acre fell (1291), the movement was allowed to depart to Cyprus. From here it moved to Rhodos (1309), then settled in Malta (1530) and eventually moved to Rome. They became known as the Hospitallers in view of their intrepid and selfless record of charitable endeavours and hospital building in particular. The best known of these were at Montpellier, Rhodos, Prussia and at various sites in Italy. The present day St.John's Ambulance evolved form the Hospitallers. The related Templars (Order of the Poor Knights of Christ and Temple of Solomon or the Teutonic Knights) remained involved in religious-military matters rather than charity, and amassed great power and wealth but was suppressed by Pope Clement V in 1312 (Major 1954: 267; Mundy 1998: 86; Chrystal 2000: 536, 1079).

5.2.3 Generally speaking, public hospitals (above) did not specialize, but certain specialized institutions did arise. Although the Basilica in Caesarea ( $4^{\text {th }}$ century) already had quarters for lepers, it is probable that leper houses (Lazar Houses; lazarettes; leprosaria) really originated during the $11^{\text {th }}$ century when Europe started experiencing an epidemic of leprosy. When this abated in the $15^{\text {th }}$ century, the leper houses were transformed by civic authorities into mainly mental asylums or infectious diseases hospitals. During the $13^{\text {th }}$ century there were 19000 leper houses in Europe, mostly run on a self-governing basis. During the early $14^{\text {th }}$ century a maternity hospital was built at Metz. There were also homes and hospitals for the aged, which partly evolved out of the monastic infirmaries, but were later run as independent charity institutions. Relatively small and often housing the apostolic number of 13 inmates, these homes were widespread and many large hospitals, like Strasbourg's St. Leonhard's and Nurnberg's Holy Ghost Hospital, had sections for the elderly. Larger Jewish communities e.g. in Cologne and Regensburg had their own hospitals (Mundy 1998: 86, 87).

\section{Islam}

With their eastern conquests consolidated and the western offensive decisively defeated at Tours by a Frankish army under Charles Martel (723), the Islamic revolution, started by Muhammed in 632, consolidated its gains and moved into a period of remarkable stability and development - the 'Golden Age of Islam', which terminated in the $13^{\text {th }}$ century. Whereas Europe was experiencing an era of socio-scientific stagnation, ended by the Renaissance, Islam succeeded in stimulating development and original thought. In spite of medical science in Europe stagnating around the doctrines of the famous Roman physician, Galen, hospitalisation did expand (as described above). In Islamic countries foreign students were welcomed, and Greek medical dogma was greatly admired, studied and translated into Arabic (which in Medieval times, became the lingua franca of science) (Major 1954: 223-225). Physicians like Rhazes (866-932), Albucasis (936-1013), Avicenna (980-1037), Avenzoar (1091-1162), Averroes (1126-1198) and Maimonides (1135-1204) made important contributions, and in the field of hospitalisation great strides were taken (Major 1954: 225-258). 
Taking their example from the Christian (Nestorian) teaching hospital at Jundi-Shapur, Islam developed its own impressive hospitals (bimaristans) at Cordoba, Baghdad, Damascus, Bokhara, Sevilla and Cairo. A total of $\mathbf{3 4}$ major ones have been identified. Tudela, who visited Baghdad in 1160, wrote that there were 60 hospitals in that city and 50 in Cordoba. The greatest and most magnificent was the Mansuri hospital in Cairo (completed in 1284). This self-contained institution had four great courts, each with a water fountain in the centre, separate wards for men and women and for different diseases, a dispensary, lecture halls, and an out-patient department from where patients were visited at their homes, a chapel and library. Fever wards were cooled by fountains. Musicians and storytellers entertained the sick, and on discharge each patient received a sum of money sufficient to pay for immediate expenses until he could resume work (Major 1954: 260; Porter 1997: 104-105; Guthrie 1958: 95, 96).

Possibly the first mental hospital for the insane (a maristan) in Europe was built by Islam in Granada in 1365 (Porter 1997: 105).

The hospitals at Cordova, Baghdad, Damascus and Cairo in particular also served as centres of medical education, attracting students from Europe and the Far East, spanning the void of Medieval scientific stagnation until the creation of Europe's own fledgling medical schools at Salerno ( $11^{\text {th }}$ century), followed by Montpellier and Bologna ( $13^{\text {th }}$ century), Padua and Paris (14 century) (Guthrie 1958: 95-96, 102-124).

\section{Discussion}

\section{The evolutionary process in summary}

There is suggestive evidence that hospitals, albeit in embryonic form, might have existed in Mesopotamia at the time of the $1^{\text {st }}$ millennium BC. The rise of Buddhism in India $\left(6^{\text {th }}\right.$ century $\mathrm{BC}$ ) was, according to rather limited evidence available to us, associated with the building of hospitals of a kind in that subcontinent, as well as in Sri Lanka. With the spread of Buddhism to the east, hospitals also appeared in China and South East Asia in pre-Christian times - usually in association with monasteries.

The ancient Greeks did not know hospitals as defined in this study, although many would argue that the healing facilities at Asclepieia represented an early form of hospitalisation.

The Roman valetudinaria, initially designed for military purposes ( $1^{\text {st }}$ century AD), represented the first true hospital, but were not open to civilians. In time a limited number of comparable institutions appeared for the imperial and civic population, slaves and gladiators. Small house hospitals (nosocomia) might have arisen out of guest rooms of well to do people, or doctors' consulting rooms (iatreia, tabernae medicae). It is in the Christian era that we first find the equivalent of our modern concept of a hospital, where civilians could receive long-term treatment - the Christians supplied significant impetus to hospital development by their establishment of caring facilities for the sick and disadvantaged in the community. Hospices for travellers and indigents gave rise to charity hospitals (xenodocheia), and the Church's monasteries became centres of medical care - the initial creation of infirmaries for inmate monks, gradually led to the establishment of hospital facilities for the civic community, pilgrims, lepers and the aged. This monastic development, which directed hospitalisation into the Middle Ages, was clearly the same process that had led to hospital expansion under monastic Buddhism, one thousand years earlier. Up to the $10^{\text {th }}$ century there were few hospitals outside the monasteries, but then Europe experienced progressive growth and diversification of hospitalisation supported by the City Fathers of large cities and by charities (including the Church). The 'Golden Age of Islam' led to the construction of magnificent hospitals in Muslim countries. Christian and Islamic hospital builders learnt from each other, but towards the $13^{\text {th }}$ and $14^{\text {th }}$ centuries Islamic hospitals were clearly more advanced than their Christian counterparts (Guthrie 1958: 95,96).

\section{References}

AELIUS ARISTIDES 1981: Aelius Aristides. Complete works. Translated by C A Behr. Leiden: E J Brill.

AITKEN J T; FULLER H W C; JOHNSOND 1984: The influence of Christians in medicine. Nottingham: Intervarsity Press.

ALLAN N 1990: Hospice to hospital in the Near East: and instance of continuity and change in late antiquity. Bull. Hist. Med. 64: 447-450.

CATO 1934: Cato and Varro. On agriculture. Translated by W D Hooper \& H B Ash. Loeb Classical Library. Cambridge Mass.: Harvard University Press.

CELSUS 1935: Celsus. On medicine. Translated by W G Spencer. Loeb Classical Library Vol. 1. Cambridge Mass.: Harvard University Press.

CHRYSTAL D (ED.) 2000: The Cambridge Encyclopedia. Fourth Edition. Cambridge: University Press.

CILLIERS L 1993: Public health in Roman legislation. Acta Classica 36: 1-10.

CODEX JUSTINIANAE 1888-1904: Corpus Juris Civilis. Codex Justinianus, recognovit P.Krüger. Berlin: Weidman.

COLUMELLA 1955: Columella. On agriculture. Translated by E S Forster \& E H. Heffner. Loeb Classical Library Vol.III. Cambridge Mass.: Harvard University Press.

CYPRIAN 1979: De mortalitate. In: Cyprian. Orations. Ed. E S Forster. New York: Arno Press.

DIGESTA 1818-1825: Pandectae Justinianae, in novum ordinem Digestae: cum legibus Codicis, et Novellis, quae jus Pandectarum confirmant, explicant aut abrogant. Auctore R J Pothier. Paris: Fournier.

EUSEBIUS 1932: Eusebius. Ecclesiastical history. Translated by J E L Oulton. Loeb Classical Library Vol. II. Cambridge Mass.: Harvard University Press.

FERNGR EN G B; AMUNDSEN D W 1996: Medicine and Christianity in the Roman Empire. In: Aufstieg und Niedergang der römische Welt. Haase W (ed.). Berlin: W. de Gruyter 
GREEN M H 1985: The transmission of ancient theories of female physiology and disease through the early Middle Ages. Ph. D. Princeton University.

GREGORY OF NAZIANZUS 1800-1875: Gregory of Nazianzus. Orations. In: Migne, J.-P. Patrologiae Graecae. Vol. xxxvi. Turnhout: Brepos Leuven, University Press.

GUTHRIE D 1958: A history of medicine. Edinburgh: Thos. Nelson \& Sons.

HAEGER K 1988: The illustrated history of medicine. London: Harold Starke.

HARIG G 1971: Zum Problem 'Krankenhaus' in der Antike. Klio53: 179-195.

HORNBLOWER S \& SPAWFORTH A (EDD.) 1996: The Oxford Classical Dictionary. Third Edition. Oxford: University Press.

JACKSON R 1988: Doctors and diseases in the Roman Empire. London: University of Oklahoma Press.

JULIAN 1923: Julian. Letters, Epigrams, Against the Galileans. Fragments. Translated by W C Wright. Loeb Classical Library. Cambridge Mass.: Harvard University Press.

LEWIS C T \& SHORT C 1958: A Latin dictionary. Oxford: Clarendon Press.

LIVY 1926: Livy. History of Rome. Translated by E T Sage. Loeb Classical Library. Cambridge Mass.: Harvard University Press.

MAJOR R H 1954: A history of medicine. Springfield Ill. Charles C. Thomas.

MAJNO G 1975: The healing hand. Man and wound in the ancient world. Cambridge Mass.: Harvard University Press.

MUNDY J H 1998: The High Middle Ages. London: Longman Group UK Ltd.

OVID 1914: Ovid. Metamorphoses. Translated by F J Miller. Loeb Classical Library. Cambridge Mass.: Harvard University Press.

PHILIPS E \& ALLAN T (EDD.) 1993: The divine campaigns AD 1100-1200. Amsterdam: Time Life Books.

PORTER R 1997: The greatest benefit to mankind. London: Harper Collins.

REINER E 1964: Medicine in ancient Mesopotamia. Journal of the International College of Surgeons 41(5): 544-549.

SCHEIDER K 1953: Valetudinarium. Realencyclopaedie der Altertumswissenschaft Band VIII.A.1, pp. 262-26. Leipzig: Mittlerische Buchgesellschaft.
SCRIPTORES HISTORIAE AUGUSTAE 1921: Scriptores Historiae Augustae. Severus Alexander. Translated by D Magie. Loeb Classical Library Vol. II. Cambridge Mass.: Harvard University Press.

SENECA 1926: Seneca. De ira. Translated by J W Basore. Loeb Classical Library Vol. 1. Cambridge Mass.: Harvard University Press.

St JEROME 1933: St. Jerome. Select letters. Translated by F A Wright. Loeb Classical Library. Cambridge Mass.: Harvard University Press.

STACCIOLI E E R 1988: Ancient Rome. Monuments past and present. Rome: La Zincografica Fiorentina.

SUETONIUS 1996: Suetonius. The lives of the Caesars. Claudius. Translated by J C Rolfe. Loeb Classical Library Vol II. Cambridge Mass.: Harvard University Press.

TACITUS 1937: Tacitus. Annales. Translated by J Jackson. Loeb Classical Library Vol. IV. Cambridge Mass.: Harvard University Press.

THOMPSON.J D \& GOLDEN G 1975: The hospital: A social and architectural study. New Haven \& London: Yale University Press.

VALERIUS MAXIMUS 2000: Valerius Maximus. Memorable doings and sayings. Translated by D R Shackleton Bailey. Loeb Classical Library. Cambridge Mass: Harvard University Press.

VITRUVIUS 1931: Vitruvius. On architecture. Translated by F Granger. Loeb Classical Library. Cambridge Mass.: Harvard University Press.

WALLACH L 1951: Alcuin. De litteris colendis. Speculum 26, Letter 56 to Eanbaldum.

WOODHEAD A G 1952: The state health service in ancient Greece. The Cambridge Historical Journal 10: 235-253. 